\title{
Seepage Study of Mapleton Lateral Canal near Mapleton, Utah, 2003
}

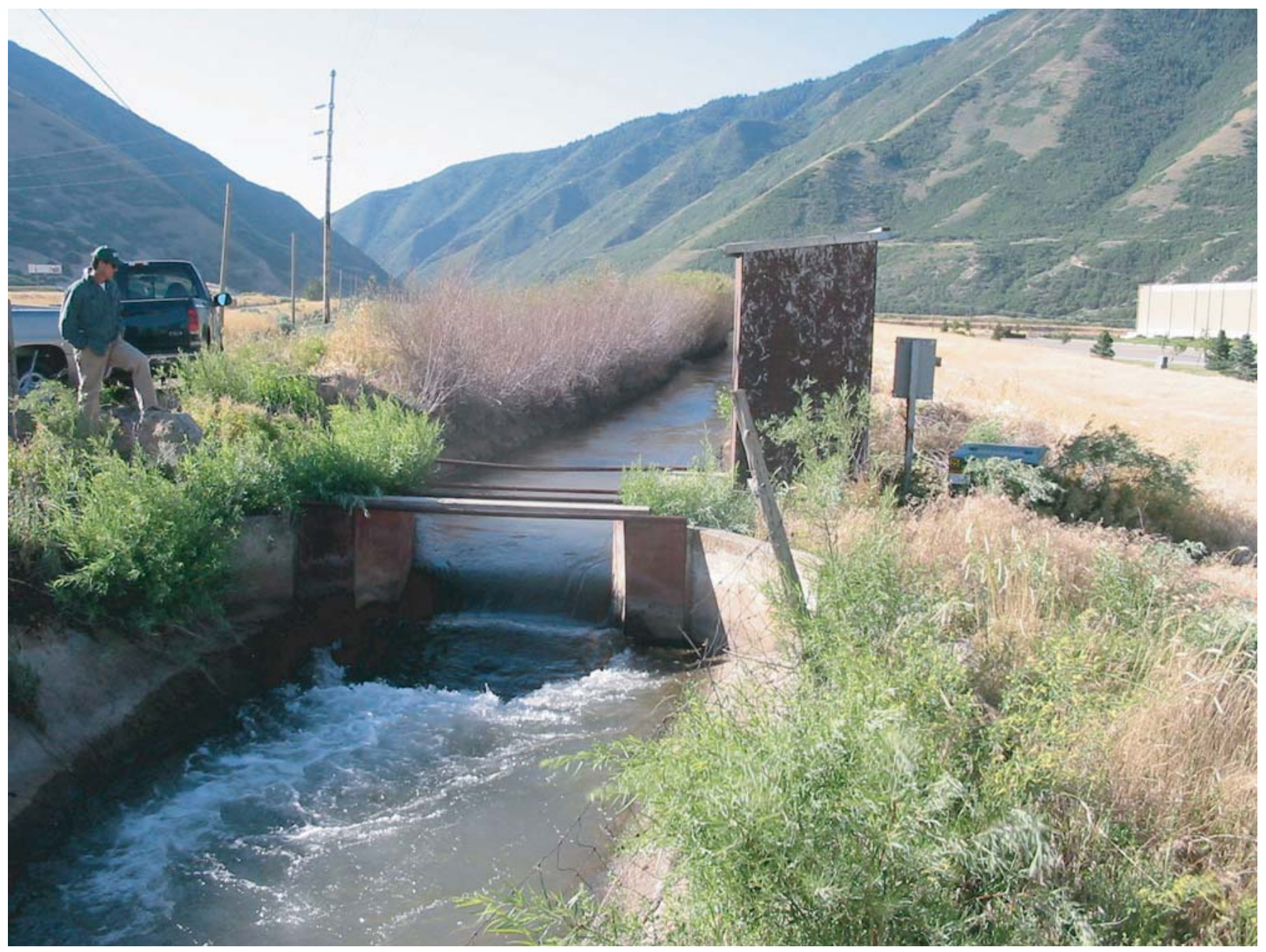

Scientific Investigations Report No. 2004-5210

Prepared in cooperation with the CENTRAL UTAH WATER CONSERVANCY DISTRICT 
Cover photograph shows Parshall Flume and water-stage recorder on Mapleton Lateral Canal near Mapleton, Utah. The flume is located on the upper end of the canal near Spanish Fork Canyon, which can be seen in the background.

Discharge in the canal was 17.3 cubic feet per second when the photograph was taken on June 27, 2003. 


\section{Seepage Study of Mapleton Lateral Canal near Mapleton, Utah, 2003}

By C.D. Wilkowske and J.V. Phillips

Scientific Investigations Report No. 2004-5210 


\title{
U.S. Department of the Interior Gale A. Norton, Secretary
}

\author{
U.S. Geological Survey \\ Charles G. Groat, Director
}

U.S. Geological Survey, Reston, Virginia: 2004

For sale by U.S. Geological Survey, Information Services

Box 25286, Denver Federal Center

Denver, Colorado 80225

\author{
For more information about the USGS and its products: \\ Telephone: 1-888-ASK-USGS \\ World Wide Web: http://www.usgs.gov/ \\ Any use of trade, product, or firm names in this publication is for descriptive purposes only and does not imply \\ endorsement by the U.S. Government. \\ Although this report is in the public domain, it contains copyrighted materials that are noted in the text. \\ Permission to reproduce those items must be secured from the individual copyright owners.
}




\section{CONTENTS}

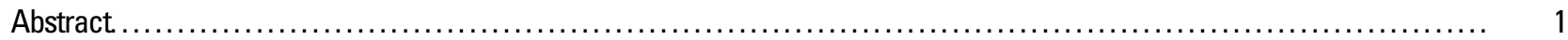

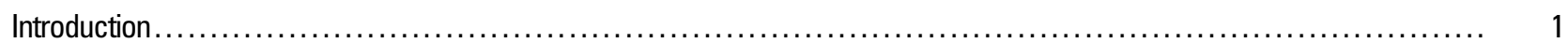

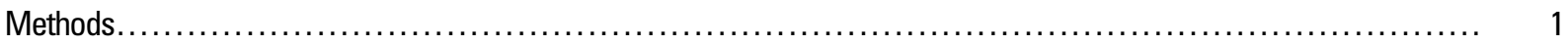

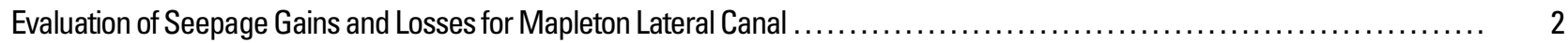

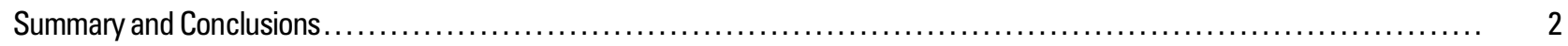

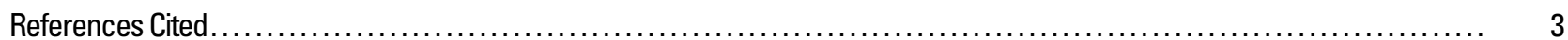

\section{Figures}

Figure 1. Map showing location of measurement sites on Mapleton Lateral Canal near Mapleton, Utah.................

Figure 2. Photograph showing measurement site ML1 and water-stage recorder at Parshall Flume on Mapleton Lateral Canal near Mapleton, Utah. . . . . . . . . . .

Figure 3. Graphs showing gage height at water-stage recorder at site ML1 on Mapleton Lateral Canal near Mapleton, Utah .... . 9

Figure 4. Graphs showing gage height at water-stage recorder at site ML6 on Mapleton Lateral Canal near Mapleton, Utah .... 10

Figure 5. Graphs showing measured and apparent average seepage gain or loss for reaches of Mapleton Lateral Canal

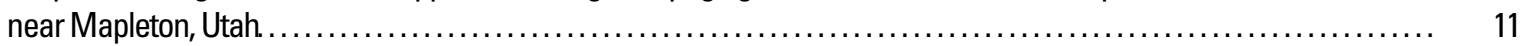

\section{Tables}

Table1. Flow, specific-conductance, and water-temperature measurements made on Mapleton Lateral Canal near

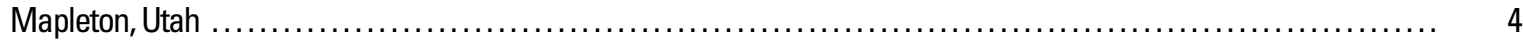

Table2. Calculated seepage gains and losses for Mapleton Lateral Canal near Mapleton, Utah . .................... 6 


\section{CONVERSION FACTORS AND DATUMS}

\begin{tabular}{rll}
\hline Multiply & By & To obtain \\
cubic foot per second $\left(\mathrm{ft}^{3} / \mathrm{s}\right)$ & 0.02832 & cubic meter per second \\
foot $(\mathrm{ft})$ & 0.3048 & meter \\
mile $(\mathrm{mi})$ & 1.609 & kilometer \\
\hline
\end{tabular}

Water temperature is reported in degrees Celsius $\left({ }^{\circ} \mathrm{C}\right)$, which can be converted to degrees Fahrenheit $\left({ }^{\circ} \mathrm{F}\right)$ by using the following equation:

$$
{ }^{\circ} \mathrm{F}=9 / 5\left({ }^{\circ} \mathrm{C}\right)+32 .
$$

Chemical concentration and water temperature are reported only in metric units. Chemical concentration is reported in milligrams per liter $(\mathrm{mg} / \mathrm{L})$ or micrograms per liter $(\mu \mathrm{g} / \mathrm{L})$. Milligrams per liter is a unit expressing the mass of solute per unit volume (liter) of water. For concentrations less than 7,000 milligrams per liter, the numerical value is about the same as for concentrations in parts per million. Specific conductance is reported in microsiemens per centimeter at 25 degrees Celsius $(\mu \mathrm{S} / \mathrm{cm})$.

Vertical coordinate information is referenced to the North American Vertical Datum of 1929 (NAVD 29). Horizontal coordinate information is referenced to the North American Datum of 1927 (NAD 27). 


\title{
Seepage Study of Mapleton Lateral Canal near Mapleton, Utah, 2003
}

\author{
By C.D. Wilkowske and J.V. Phillips
}

\section{Abstract}

A study was conducted during the summer of 2003 on Mapleton Lateral Canal near Mapleton, Utah, to determine gain or loss of flow in the canal from seepage. Measurements were made in May, June, July, and September of 2003. The uppermost reach of the canal had an apparent average loss of 2.6 cubic feet per second. The next reach downstream showed an apparent average gain of 1.4 cubic feet per second. The next three downstream reaches had apparent average losses of 2.4, 2.5 , and 2.7 cubic feet per second. The apparent average net loss from the canal was 8.8 cubic feet per second, or a loss of 30 percent of the total discharge measured at the head of the canal.

\section{Introduction}

Information on seepage gains and losses is needed by water managers at the Central Utah Water

Conservancy District (CUWCD) to determine the total amount of water lost to the subsurface in an approximate 6-mi stretch of the Mapleton Lateral Canal located between the mouth of Spanish Fork Canyon and the city of Mapleton, Utah (fig. 1). The canal is approximately 10 to $15 \mathrm{ft}$ in width and is mostly of earthen construction except for a small section lined with concrete. Flow in the canal generally occurs during May through September, the primary irrigation season. This report describes the methods used to obtain flow measurements made along Mapleton Lateral Canal from May to September to determine the amount of seepage gains and losses and discusses the results of four sets of measurements.

\section{Methods}

A reconnaissance of the canal was completed during the summer of 2002. The canal was examined for general conditions, location of control and turnout structures, and areas of natural and irrigation-return flows. Six measuring sites (ML1 to ML6) on the main canal were selected (fig. 1) with the information collected during the reconnaissance. During each set of flow measurements, water-stage recorders were operated at the upstream and downstream end of the canal to determine any change in stage. The upstream recorder was a float-driven electronic data recorder installed by the U.S. Geological Survey (USGS) and located in a Parshall Flume at station ML1 (fig. 1). A photograph of this station is shown in figure 2. The downstream recorder was an existing recorder in a flume that is operated by the Springville Canal Company and is located at site ML6 (fig. 1).

Four sets of flow measurements were made during the summer of 2003. The measurements were made on May 30, June 27, July 30, and September 3, 2003. Each set consisted of flow measurements at selected sites along the main canal, and flow measurements into and out of the diversions that were in use.

Flow measurements were made using standard methods of the USGS (Buchanan and Somers, 1969). For each set of flow measurements, the date, time, and amount from each measurement location are listed in table 1. Specific conductance and water temperature were measured on September 3 with a YSI 600QS multiparameter meter that was calibrated with certified specific-conductance standards. Seepage gains and losses along the reaches were calculated by subtracting the downstream flow measurement from the next upstream flow measurement and then adding in any turnouts (TO) and subtracting the return flows (R). An average value for the four sets of flow measurements was calculated for each reach. These averages are considered 


\section{Seepage study of the Mapleton Lateral Canal near Mapleton, Utah}

apparent averages because of the uncertainty of changing seepage with changing flow conditions during the irrigation season.

Water-stage records from the upstream recorder are shown in figure 3 , and records from the downstream recorder are shown in figure 4 . Flows in the canal and the diversions generally were held constant during the measurements, except on May 30, 2003, when the diversion at TO8, located between ML4 and ML5, was closed. Flow on May 30, 2003, at station ML5 was measured at 11:30 and at ML6 at 11:15. The diversion at TO8 was closed at 9:10. This allowed for sufficient time for flow at station ML5 to reach a steady-state condition. The seepage loss measured between stations ML4 and ML5 was therefore calculated by using no flow at the diversion at TO8. The flow measurement made at station ML6 was made as the stage in the canal was rising (fig. 3 ); therefore, this measurement should be considered a minimum flow for the station.

\section{Evaluation of Seepage Gains and Losses for Mapleton Lateral Canal}

All of the flow measurements made for each of the four measurement dates are shown in table 1 . The computed gain or loss and distance for each of the five reaches is shown in figure 5. During the summer, the seepage varied within each individual reach. This variation is shown by the scatter of the plotted points in figure 5. A plot of the apparent average seepage gain or loss in relation to the measured seepage also is shown in figure 5. The calculated seepage gain or loss for each measurement, and the apparent average gain or loss for all the Mapleton Lateral Canal reaches is shown in table 2. The total gain or loss is also shown as a percentage of the flow measured at station ML1.

Reach ML1 to ML2 showed a consistent loss for all measurement dates (fig. 5). The seepage loss ranged from $0.2 \mathrm{ft}^{3} / \mathrm{s}$ on June 27,2003 , to $5.5 \mathrm{ft}^{3} / \mathrm{s}$ on July 30 , 2003. The apparent average seepage loss for the reach was $2.6 \mathrm{ft}^{3} / \mathrm{s}$ or about $2.0 \mathrm{ft}^{3} / \mathrm{s}$ per mi (table 2).

Reach ML2 to ML3 showed a consistent net gain for all measurement dates (fig. 5). The greatest gains occurred during the first two dates in May and June. During this period, the apparent average gain to the reach was $2.5 \mathrm{ft}^{3} / \mathrm{s}$. During the July and September measurements, the apparent average gain to the reach was only $0.4 \mathrm{ft}^{3} / \mathrm{s}$. The apparent average gain throughout the summer was $1.4 \mathrm{ft}^{3} / \mathrm{s}$ or $1.3 \mathrm{ft}^{3} / \mathrm{s}$ per mi (table 2 ). A short section of the canal is lined with concrete in this reach; however, because of the scale of the measurements, no effect from the concrete could be determined.

Reach ML3 to ML4 showed a consistent seepage loss for all measurements. The greatest seepage loss occurred during the first two measurements in May and June. The apparent average loss during this period was 4 $\mathrm{ft}^{3} / \mathrm{s}$. During July through September the loss was only $0.8 \mathrm{ft}^{3} / \mathrm{s}$. This pattern is not seen in any other losing canal reach and may have been caused by entrapment of air or fine sediment along the canal bed that decreased the seepage rate during the latter part of the summer. The apparent average loss for this reach was $2.4 \mathrm{ft}^{3} / \mathrm{s}$ or 2.6 $\mathrm{ft}^{3} /$ s per mi (table 2 ).

Reach ML4 to ML5 showed a consistent loss for all measurements. The seepage loss ranged from $1.0 \mathrm{ft}^{3} / \mathrm{s}$ at the end of June to $5.3 \mathrm{ft}^{3} / \mathrm{s}$ at the end of July. The highest seepage loss coincided with the highest flow in the canal. The apparent average loss for this reach was $2.5 \mathrm{ft}^{3} / \mathrm{s}$ or $3.0 \mathrm{ft}^{3} / \mathrm{s}$ per mi (table 2 ).

Reach ML5 to ML6 showed a consistent loss for all measurements except that measured on June 27, 2003, which showed no net gain or loss. The highest seepage loss occurred on July 30, 2003, which coincided with the highest flow measured in the canal. Seepage loss measured on May 30, 2003, should be considered a maximum loss value because the flow at station ML6 was rising during the measurements. Assuming the diversions at TO10 and TO12 were not affected by the closure of TO8, a greater flow at this station would have resulted in a lower net loss along the reach. The apparent average loss for this reach was $2.7 \mathrm{ft}^{3} / \mathrm{s}$ or $1.8 \mathrm{ft}^{3} / \mathrm{s}$ per mi (table 2).

\section{Summary and Conclusions}

A seepage study was done on Mapleton Lateral Canal to determine the total amount of water lost to the subsurface in the approximately 6-mi stretch between the mouth of Spanish Fork Canyon and the city of Mapleton, Utah. The canal showed a net loss of water during each set of four flow measurements. The apparent average net losses ranged from $1.4 \mathrm{ft}^{3} / \mathrm{s}$ measured on June 27, 2003, to $15.4 \mathrm{ft}^{3} / \mathrm{s}$ measured July 30,2003 . The apparent average net loss from the canal was $8.8 \mathrm{ft}^{3} / \mathrm{s}$ (table 2). The loss percentage ranged from 8 percent of flow at station ML1 on June 27, 2003, to 43 percent loss on September 3, 2003. The apparent average loss 
percentage was 30 percent. In general, the greatest seepage losses were recorded during the July 30, 2003, measurement when the flow in the canal was the greatest.

The greatest percentage loss of 43 percent occurred during the September measurement. With the exception of the June 27, 2003, measurement, percentage losses appeared to generally increase throughout the summer. It is not clear why the lowest seepage losses were measured during the June 27, 2003, measurement. Reach ML2 to ML3 showed a consistent gain during each measurement. This section of the canal cuts across a hillslope that could be contributing shallow subsurface flow to the canal during the wetter periods of spring and early summer. During the latter part of July and during September, the seepage gain in this section was considerably less.

In general, the reaches displayed consistent gains and losses over the course of four sets of measurements during the summer. All of the canal reaches showed an apparent average net loss during the four measurement sets except for reach ML2 to ML3, which showed an apparent average net gain. Variations in the magnitude of the gains and losses were a result of changes of stage in the canal, different wetting conditions in the canal material, and changes in natural seepage gains to the canal.

\section{References Cited}

Buchanan, T.J., and Somers, W.P., 1969, Discharge measurements at gaging stations: U.S. Geological Survey Techniques of Water-Resources Investigations, book 3, chap. A8, 66 p. 


\section{Seepage study of the Mapleton Lateral Canal near Mapleton, Utah}

Table 1. Flow, specific-conductance, and water-temperature measurements made on Mapleton Lateral Canal near Mapleton, Utah

[Site: See figure 1 for location of site; ML, canal; TO, irrigation turnout; R, return flow; e, estimated]

\begin{tabular}{|c|c|c|c|c|}
\hline Site & $\begin{array}{c}\text { Flow } \\
\text { (cubic feet } \\
\text { per second) }\end{array}$ & Time & $\begin{array}{l}\text { Specific conductance } \\
\text { (microsiemens } \\
\text { per centimeter } \\
\text { at } 25 \text { degrees } \\
\text { Celsius) }\end{array}$ & $\begin{array}{c}\text { Water } \\
\text { temperature } \\
\text { (degrees } \\
\text { Celsius) }\end{array}$ \\
\hline \multicolumn{5}{|c|}{ May 30, 2003} \\
\hline ML1 & 31.10 & $7: 15$ & & \\
\hline ML2 & 28.90 & $8: 35$ & & \\
\hline TO1 & .00 & & & \\
\hline TO2 & .00 & & & \\
\hline TO3 & 2.98 & $7: 40$ & & \\
\hline ML3 & 28.00 & $9: 50$ & & \\
\hline TO4 & .00 & & & \\
\hline TO5 & 6.56 & $8: 10$ & & \\
\hline ML4 & 16.50 & $10: 40$ & & \\
\hline TO6 & .00 & & & \\
\hline TO7 & .00 & & & \\
\hline $\mathrm{R} 1$ & .20 & $8: 25$ & & \\
\hline TO8 & 5.10 & ${ }^{1} 08: 30$ & & \\
\hline $\mathrm{R} 2$ & .00 & & & \\
\hline ML5 & 14.60 & $11: 30$ & & \\
\hline $\mathrm{R} 3$ & 6.33 & 9:00 & & \\
\hline TO9 & .00 & & & \\
\hline TO10 & 7.88 & $9: 40$ & & \\
\hline $\mathrm{R} 4$ & .00 & & & \\
\hline TO11 & .00 & & & \\
\hline $\mathrm{R} 5$ & 4.95 & $10: 20$ & & \\
\hline TO12 & 7.13 & $10: 40$ & & \\
\hline ML6 & 6.59 & $11: 15$ & & \\
\hline \multicolumn{5}{|c|}{ June 27, 2003} \\
\hline ML1 & 17.30 & $7: 50$ & & \\
\hline ML2 & 17.10 & 9:00 & & \\
\hline TO1 & .00 & & & \\
\hline TO2 & .00 & & & \\
\hline TO3 & .00 & & & \\
\hline ML3 & 20.00 & $9: 55$ & & \\
\hline TO4 & .00 & & & \\
\hline TO5 & .22 & $8: 10$ & & \\
\hline ML4 & 16.70 & $10: 45$ & & \\
\hline TO6 & .00 & & & \\
\hline TO7 & .00 & & & \\
\hline $\mathrm{R} 1$ & $.03 \mathrm{e}$ & $8: 15$ & & \\
\hline TO8 & $.10 \mathrm{e}$ & $8: 20$ & & \\
\hline $\mathrm{R} 2$ & .00 & & & \\
\hline ML5 & 15.60 & $11: 20$ & & \\
\hline R3 & 4.75 & $8: 45$ & & \\
\hline TO9 & 6.66 & $9: 10$ & & \\
\hline
\end{tabular}


Table 1. Flow, specific-conductance, and water-temperature measurements made on Mapleton Lateral Canal near Mapleton, Utah-Continued

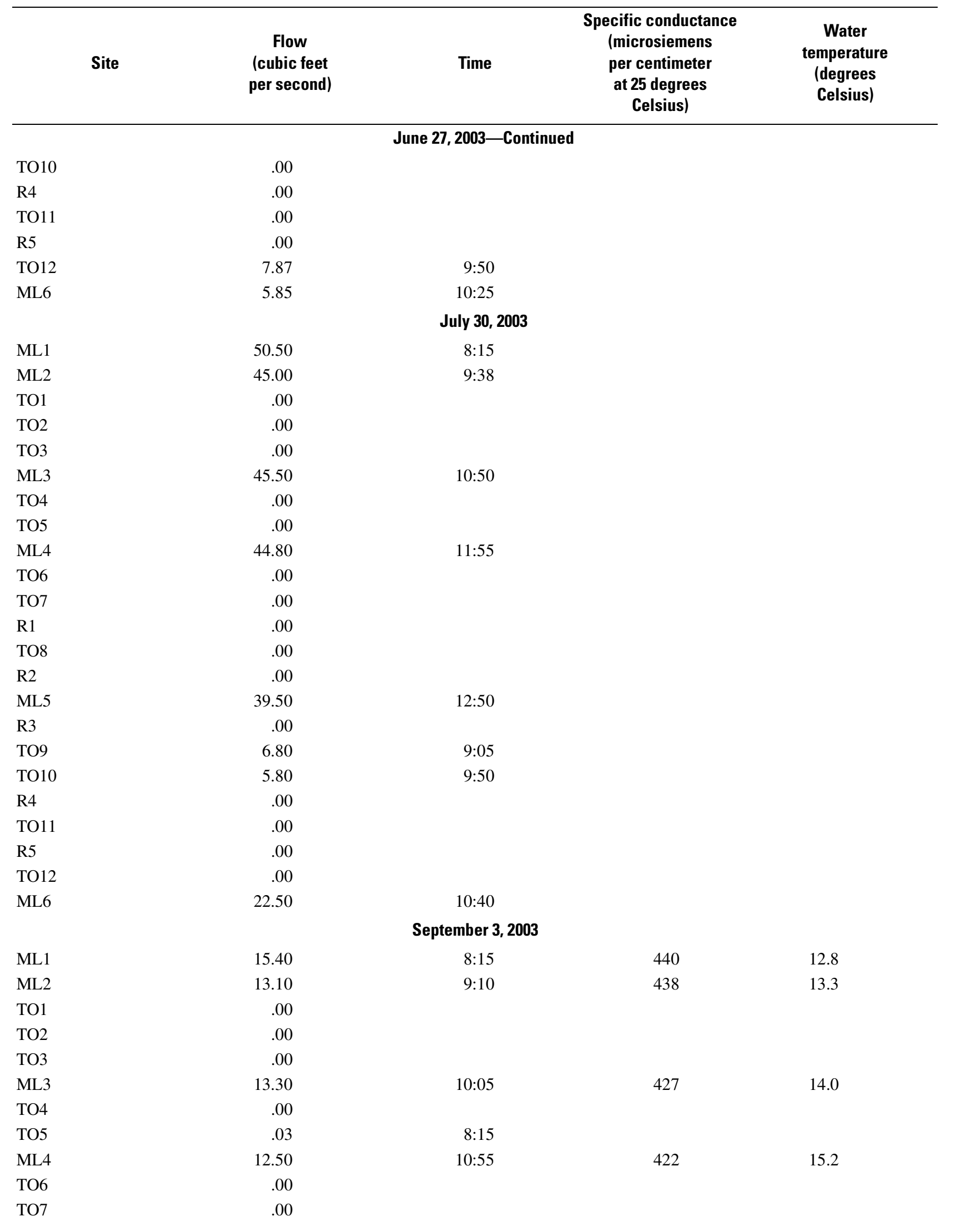




\section{Seepage study of the Mapleton Lateral Canal near Mapleton, Utah}

Table 1. Flow, specific-conductance, and water-temperature measurements made on Mapleton Lateral Canal near Mapleton, Utah-Continued

\begin{tabular}{|c|c|c|c|c|}
\hline Site & $\begin{array}{c}\text { Flow } \\
\text { (cubic feet } \\
\text { per second) }\end{array}$ & Time & $\begin{array}{l}\text { Specific conductance } \\
\text { (microsiemens } \\
\text { per centimeter } \\
\text { at } 25 \text { degrees } \\
\text { Celsius) }\end{array}$ & $\begin{array}{c}\text { Water } \\
\text { temperature } \\
\text { (degrees } \\
\text { Celsius) }\end{array}$ \\
\hline \multicolumn{5}{|c|}{ September 3, 2003-Continued } \\
\hline R1 & $.01 \mathrm{e}$ & 8:45 & & \\
\hline TO8 & .00 & & & \\
\hline R2 & .00 & & & \\
\hline ML5 & 10.90 & 11:05 & 422 & 15.8 \\
\hline R3 & .87 & 9:05 & & \\
\hline TO9 & .00 & & & \\
\hline TO10 & .00 & & & \\
\hline R4 & .00 & & & \\
\hline TO11 & .00 & & & \\
\hline R5 & .00 & & & \\
\hline TO12 & $.05 \mathrm{e}$ & $9: 40$ & & \\
\hline ML6 & 9.54 & $9: 45$ & 425 & 17.2 \\
\hline
\end{tabular}

${ }^{1}$ TO8 was shut off at 09:10.

Table 2. Calculated seepage gains and losses for Mapleton Lateral Canal near Mapleton, Utah

\begin{tabular}{|c|c|c|c|c|c|c|c|}
\hline Reach & $\begin{array}{l}\text { Length } \\
\text { (miles) }\end{array}$ & $\begin{array}{l}\text { May 30, } 2003 \\
\text { gain }(+) \text { or } \\
\text { loss }(-) \text {, } \\
\text { in cubic feet } \\
\text { per second }\end{array}$ & $\begin{array}{l}\text { June 27, } 2003 \\
\text { gain }(+) \text { or } \\
\text { loss }(-), \\
\text { in cubic feet } \\
\text { per second }\end{array}$ & $\begin{array}{c}\text { July } 30,2003 \\
\text { gain }(+) \text { or } \\
\text { loss }(-), \\
\text { in cubic feet } \\
\text { per second }\end{array}$ & $\begin{array}{l}\text { September 3,2003 } \\
\text { gain }(+) \text { or } \\
\text { loss }(-), \\
\text { in cubic feet } \\
\text { per second }\end{array}$ & $\begin{array}{c}\text { Apparent } \\
\text { average gain (+) } \\
\text { or loss }(-) \text { of } \\
\text { reach, } \\
\text { in cubic feet } \\
\text { per second }\end{array}$ & $\begin{array}{c}\text { Apparent } \\
\text { average gain (+) } \\
\text { or loss }(-) \text {, } \\
\text { in cubic feet per } \\
\text { second } \\
\text { per mile }\end{array}$ \\
\hline ML1-ML2 & 1.31 & -2.2 & -0.2 & -5.5 & -2.3 & -2.6 & -2.0 \\
\hline ML2-ML3 & 1.11 & 2.1 & 2.9 & .5 & .2 & 1.4 & 1.3 \\
\hline ML3-ML4 & .91 & -4.9 & -3.1 & -.7 & -.8 & -2.4 & -2.6 \\
\hline ML4-ML5 & .83 & -2.1 & -1.0 & -5.3 & -1.6 & -2.5 & -3.0 \\
\hline ML5-ML6 & 1.53 & ${ }^{1}-4.3$ & .0 & -4.4 & -2.2 & -2.7 & -1.8 \\
\hline TOTAL & & -11.4 & -1.4 & -15.4 & -6.7 & -8.8 & \\
\hline Percent of ML1 & & -37 & -8 & -30 & -43 & -30 & \\
\hline
\end{tabular}

1 TO8 was shut off during this measurement; this value should be considered a maximum loss value. 


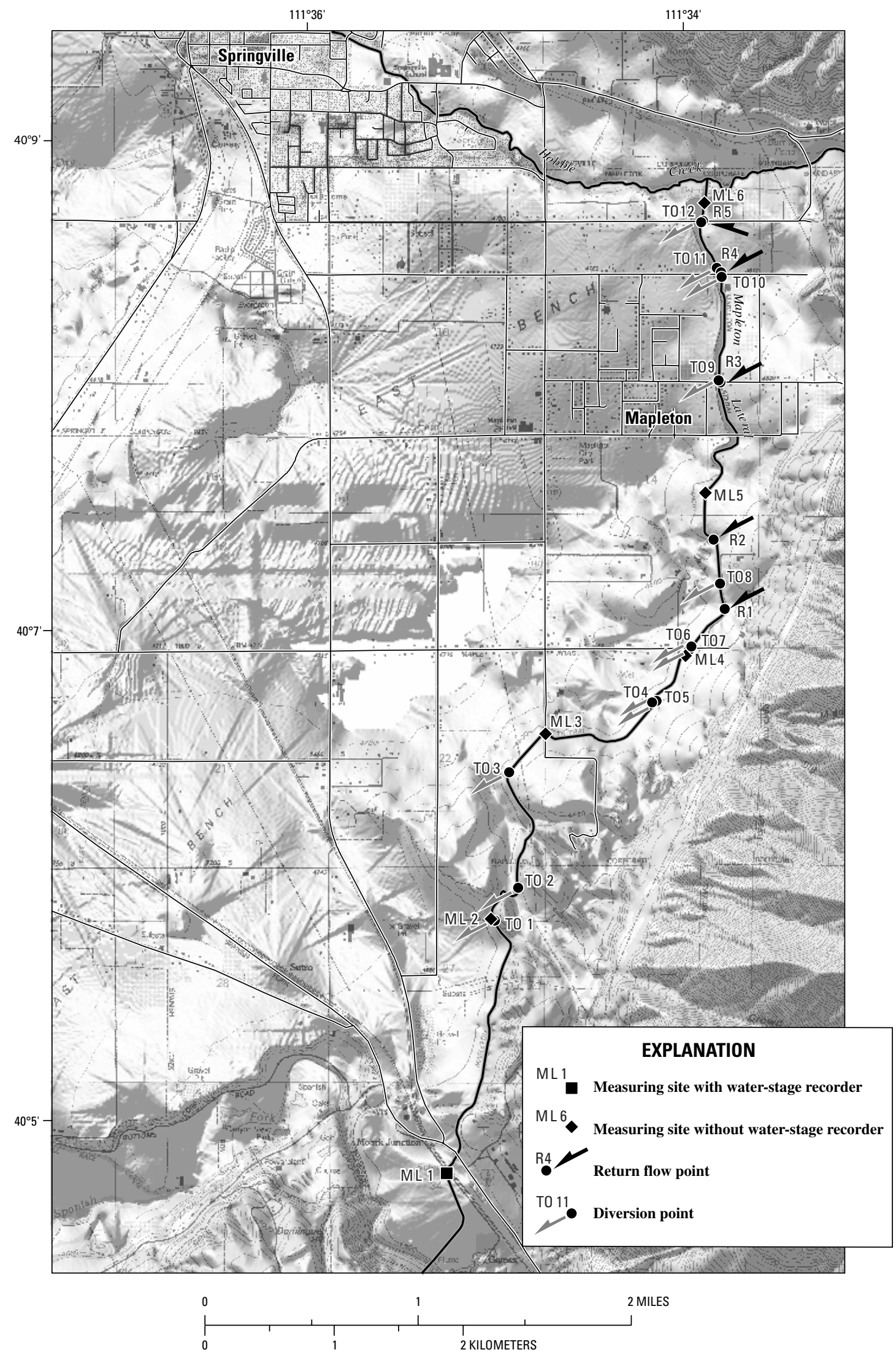

Figure 1. Location of measurement sites on Mapleton Lateral Canal near Mapleton, Utah. 


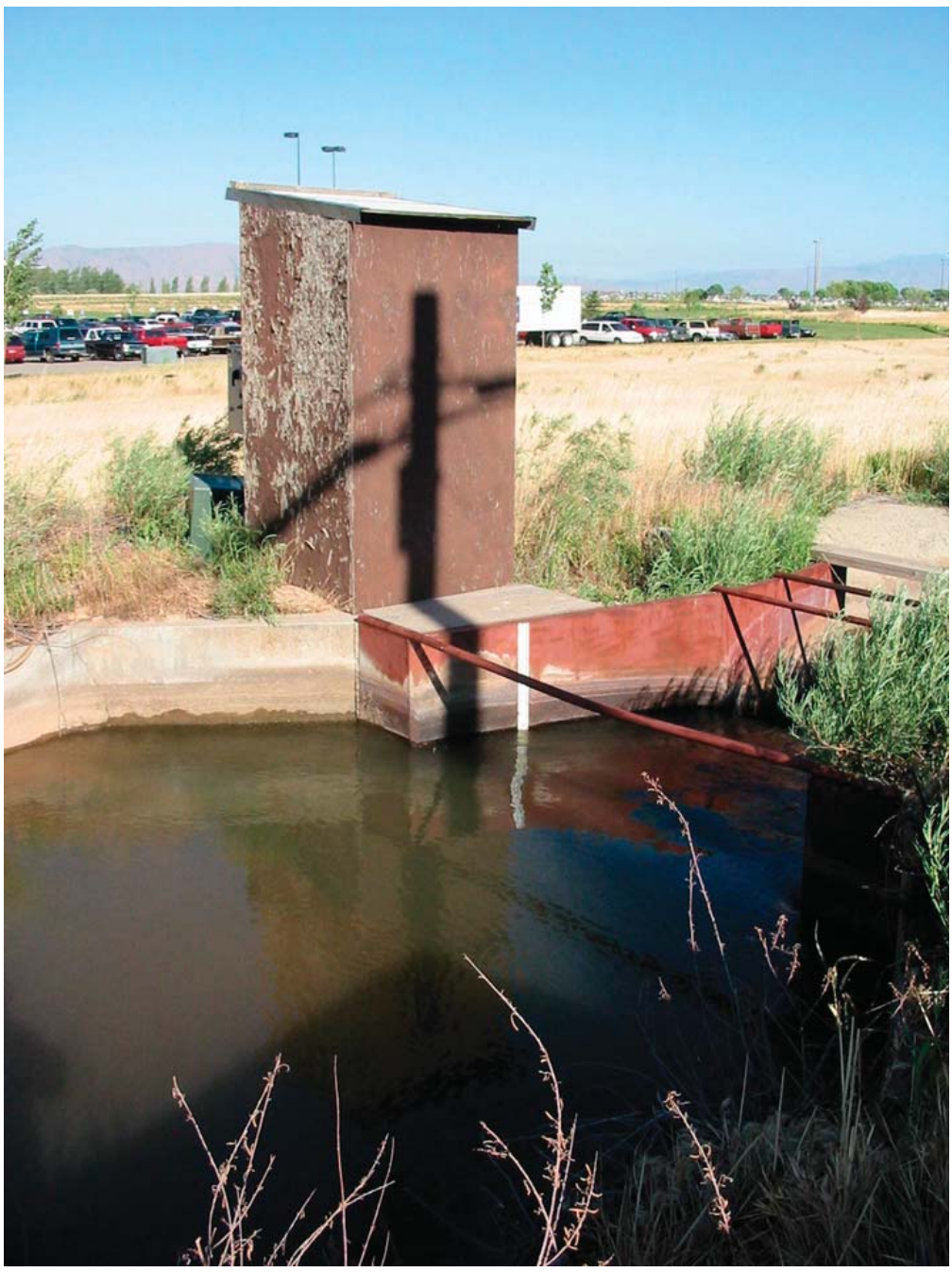

Figure 2. Measurement site ML1 and water-stage recorder at Parshall Flume on Mapleton Lateral Canal near Mapleton, Utah. 


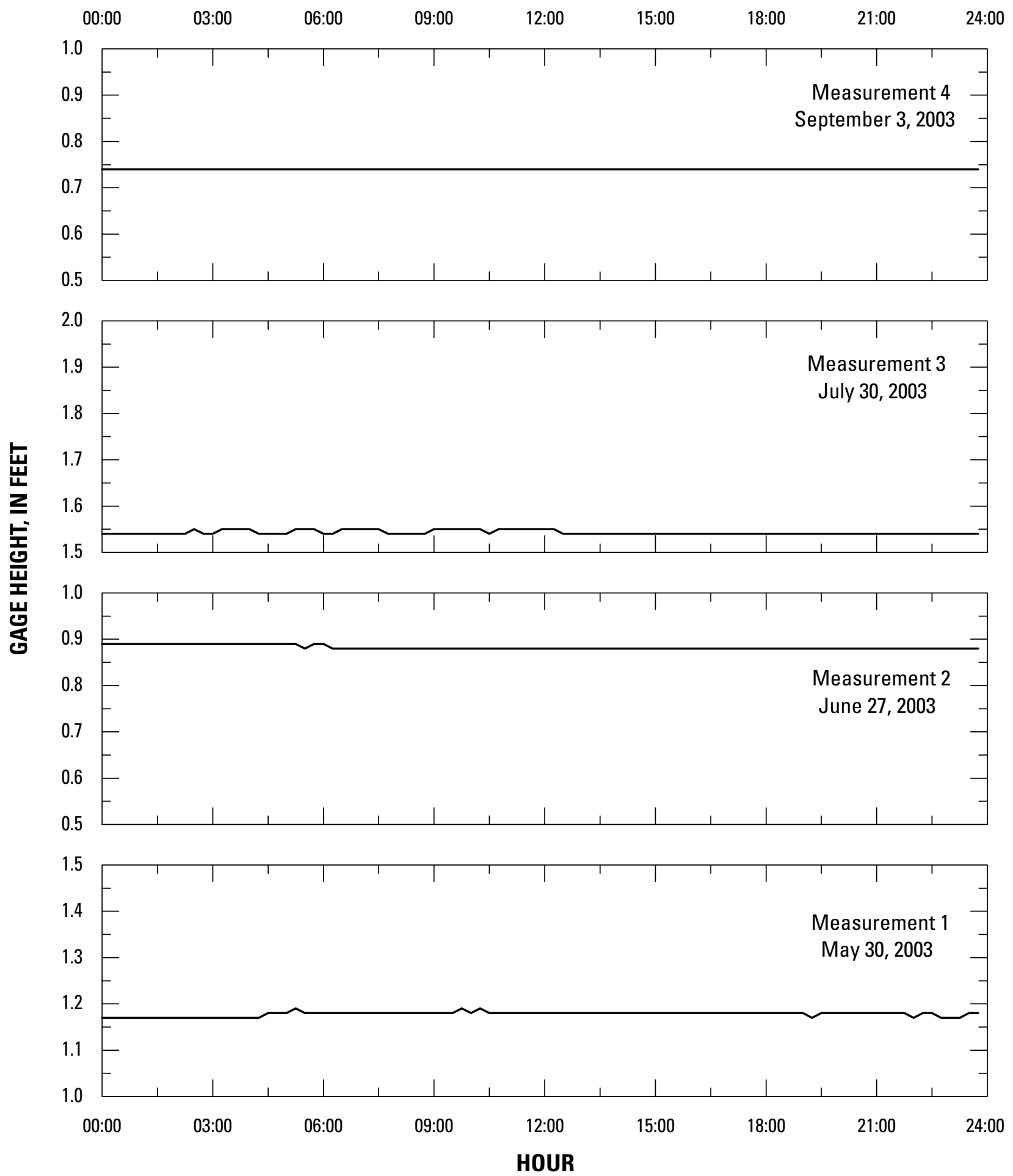

Figure 3. Gage height at water-stage recorder at site ML1 on Mapleton Lateral Canal near Mapleton, Utah. 


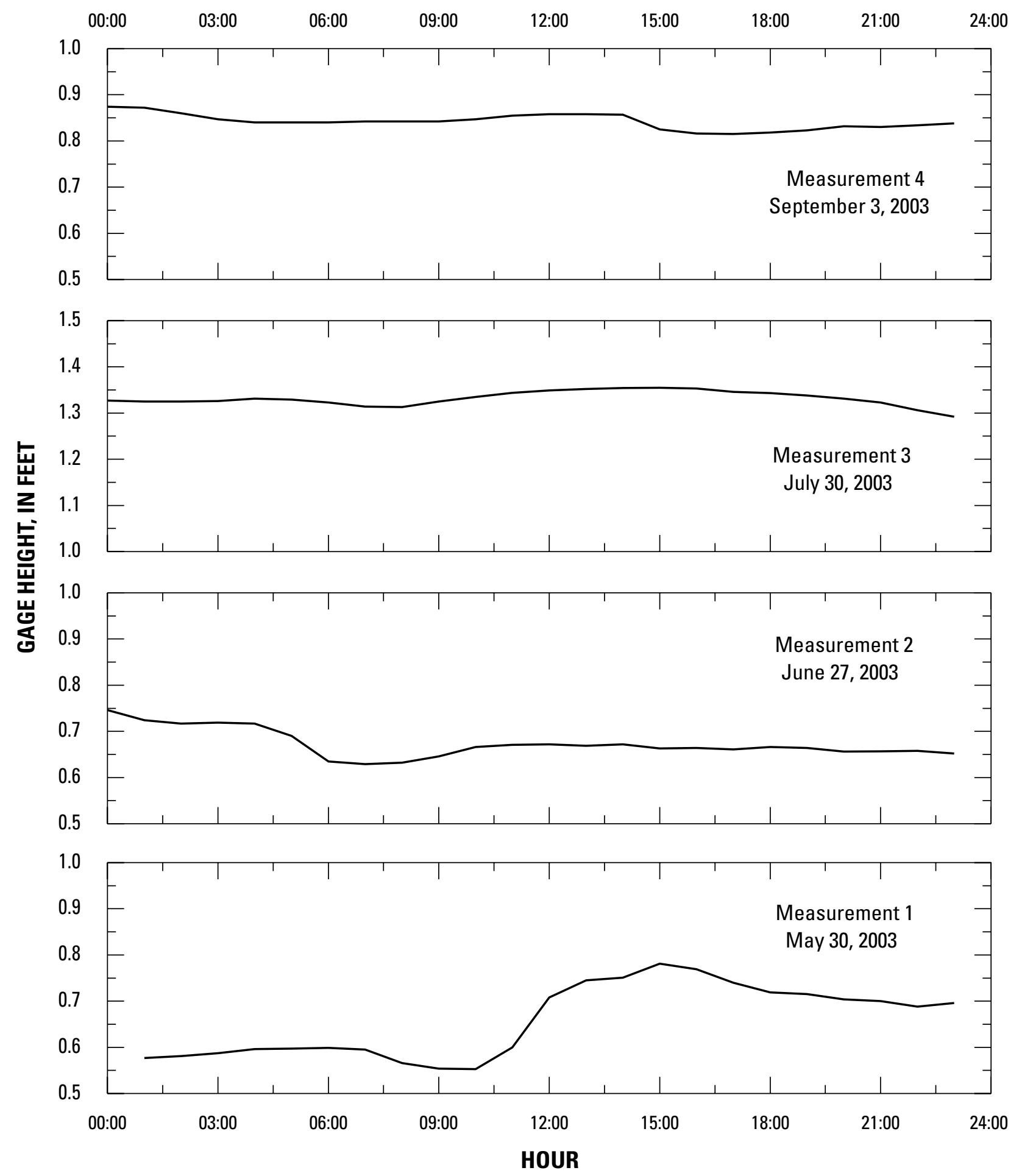

Figure 4. Gage height at water-stage recorder at site ML6 on Mapleton Lateral Canal near Mapleton, Utah. 

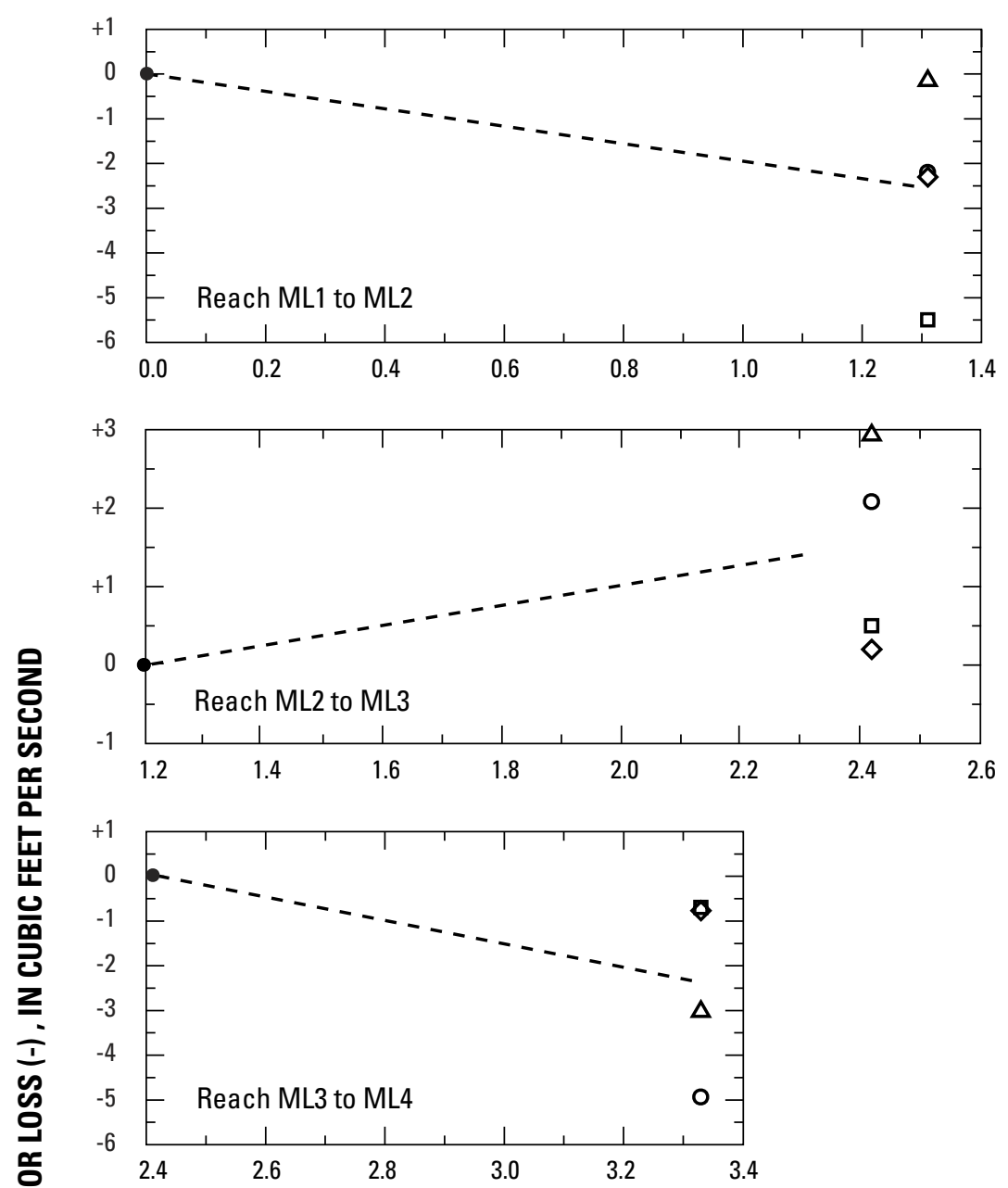

\section{EXPLANATION}

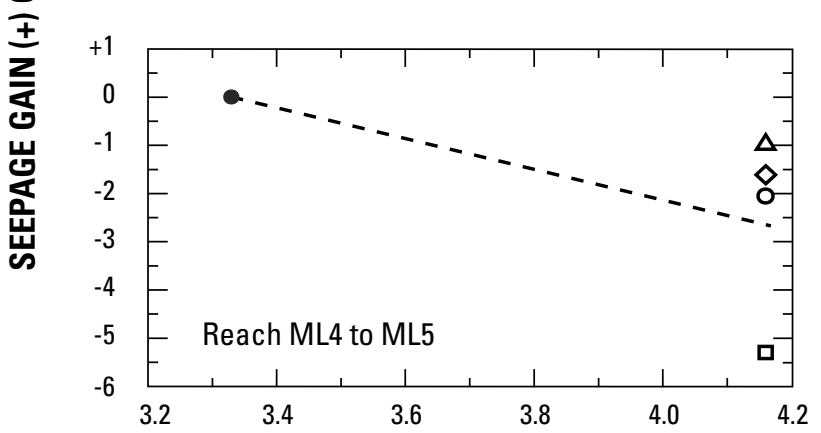

- - - Apparent average seepage

- Point from which change was computed

- Seepage measurement of May 30, 2003

$\Delta$ Seepage measurement of June 27, 2003

․ Seepage measurement of July 30, 2003

$\diamond$ Seepage measurement of September 3, 2003

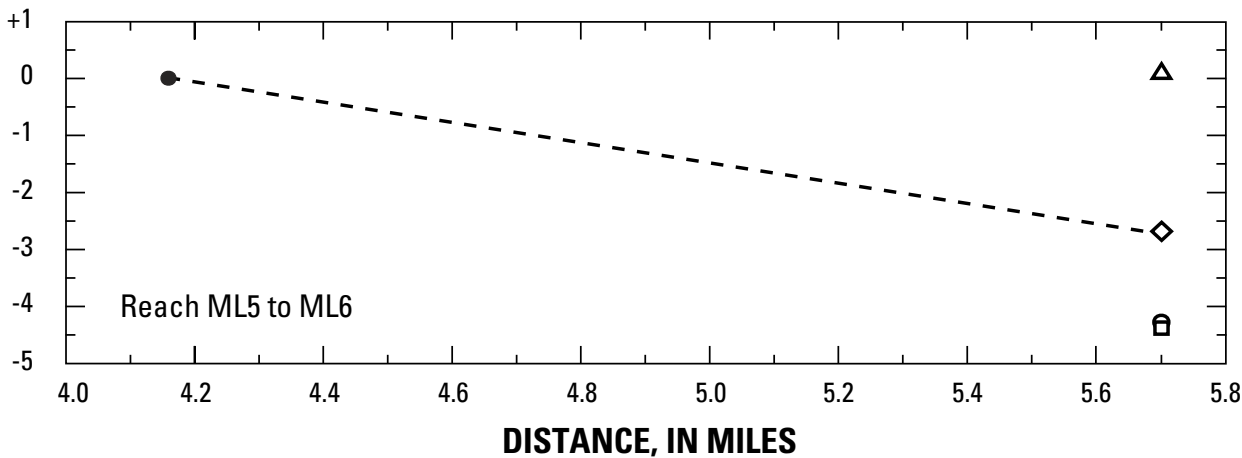

Figure 5. Measured and apparent average seepage gain or loss for reaches of Mapleton Lateral Canal near Mapleton, Utah. 
12 Seepage study of the Mapleton Lateral Canal near Mapleton, Utah 